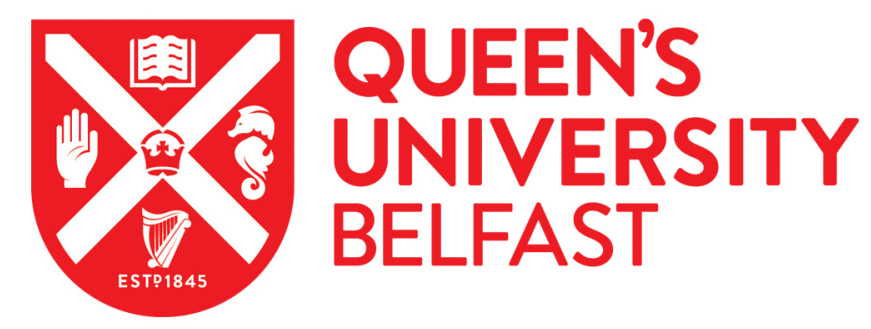

\title{
In vitro bioassay investigations of suspected obesogen monosodium glutamate at the level of nuclear receptor binding and steroidogenesis
}

Shannon, M., Wilson, J., Xie, Y., \& Connolly, L. (2019). In vitro bioassay investigations of suspected obesogen monosodium glutamate at the level of nuclear receptor binding and steroidogenesis. Toxicology Letters, $301,11-$ 16. https://doi.org/10.1016/j.toxlet.2018.10.021

Published in:

Toxicology Letters

Document Version:

Peer reviewed version

Queen's University Belfast - Research Portal:

Link to publication record in Queen's University Belfast Research Portal

Publisher rights

(c) 2018 Elsevier B. V.

This manuscript version is made available under the CC-BY-NC-ND 4.0 license http://creativecommons.org/licenses/by-nc-nd/4.0/,which permits distribution and reproduction for noncommercial purposes, provided the author and source are cited

\section{General rights}

Copyright for the publications made accessible via the Queen's University Belfast Research Portal is retained by the author(s) and / or other copyright owners and it is a condition of accessing these publications that users recognise and abide by the legal requirements associated with these rights.

Take down policy

The Research Portal is Queen's institutional repository that provides access to Queen's research output. Every effort has been made to ensure that content in the Research Portal does not infringe any person's rights, or applicable UK laws. If you discover content in the Research Portal that you believe breaches copyright or violates any law, please contact openaccess@qub.ac.uk. 


\section{Accepted Manuscript}

Title: In vitro bioassay investigations of suspected obesogen Monosodium Glutamate at the level of nuclear receptor binding and steroidogenesis

Authors: Maeve Shannon, Jodie Wilson, Yuling Xie, Lisa Connolly

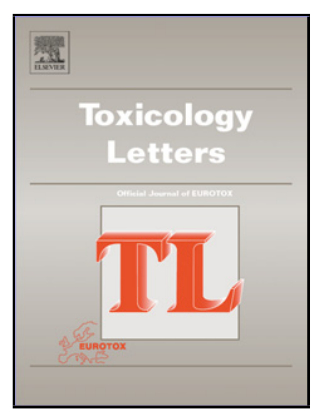

PII: S0378-4274(18)32026-5

DOI: https://doi.org/10.1016/j.toxlet.2018.10.021

Reference: TOXLET 10348

To appear in: Toxicology Letters

Received date: 24-4-2018

Revised date: $5-9-2018$

Accepted date: 22-10-2018

Please cite this article as: Shannon M, Wilson J, Xie Y, Connolly L, In vitro bioassay investigations of suspected obesogen Monosodium Glutamate at the level of nuclear receptor binding and steroidogenesis, Toxicology Letters (2018), https://doi.org/10.1016/j.toxlet.2018.10.021

This is a PDF file of an unedited manuscript that has been accepted for publication. As a service to our customers we are providing this early version of the manuscript. The manuscript will undergo copyediting, typesetting, and review of the resulting proof before it is published in its final form. Please note that during the production process errors may be discovered which could affect the content, and all legal disclaimers that apply to the journal pertain. 


\section{In vitro bioassay investigations of suspected obesogen Monosodium}

\section{Glutamate at the level of nuclear receptor binding and steroidogenesis}

Maeve Shannon ${ }^{1}$, Jodie Wilson ${ }^{1}$, Yuling Xie ${ }^{1}$ and Lisa Connolly ${ }^{1 *}$

${ }^{1}$ Institute for Global Food Security, School of Biological Sciences, Queen's University, Belfast, Northern Ireland, United Kingdom.

*Corresponding author and person to whom reprint requests should be addressed:

Dr. Lisa Connolly

Institute for Global Food Security

Queen's University Belfast

18-30 Malone Road Belfast, BT9 5BN

Phone: $+44(0) 2890976668$

Email: I.connolly@qub.ac.uk

\section{Highlights}

- Monosodium glutamate (MSG) is a suspected obesogen.

- There is a link between exposure to MSG and alterations in steroid hormone levels.

- MSG can antagonise the androgen receptor in a dose dependent manner.

- The androgen receptor plays an important role in regulating metabolic homeostasis and is an emerging target for diabetes and obesity. 


\section{Abstract}

Monosodium glutamate (MSG) is a commonly used flavour enhancer in households, catering and food production. Recently it has been highlighted as a suspected dietary obesogen in epidemiological studies indicating a link between MSG consumption and weight gain. Additionally, animal studies have shown that MSG exposure has profound effects on sex steroid hormone levels and receptors; which have an important role in energy metabolism. However, the exact mechanism by which MSG exerts its effects has yet to be elucidated. Reporter gene assays (RGAs) and the H295R steroidogenesis assay have been used to investigate the endocrine disrupting potential of MSG. Receptor (ant) agonism was not observed in the MMV-Luc (oestrogen responsive) or TM-Luc (progestagen responsive) cell lines following exposure to MSG. Also, no effects on hormone production were observed. However, MSG exhibited an antagonist response in the androgen and progestagen responsive TARM-Luc cell line, with a dose dependent reduction in androgen response of $33 \%$, $36.9 \%$ and $50.6 \%$ (in comparison to the solvent control) at 50,250 and $500 \mu \mathrm{g} / \mathrm{ml}$ MSG, respectively $(P \leq 0.05 ; P \leq 0.05 ; P \leq 0.001)$. No cytotoxicity or pre lethal cytotoxicity was observed at the concentrations tested. These findings demonstrate one potential pathway whereby MSG may act as a dietary obesogen.

Abbreviations: ADI; Acceptable Daily Intake, ANOVA; a one-way analysis of variance, AR; androgen receptor, dH20; deionised water, DMSO; dimethyl sulfoxide, EAAT-1; excitatory amino acid transporter, EDCs; endocrine disrupting compounds, EFSA; European Food 
Safety Authority, ELISA; enzyme-linked immunosorbent assay, HCA; high content analysis, HCS; high content screening, MSG; monosodium glutamate, MTT; thiazolyl blue tetrazolium bromide, POPs; persistent organic pollutants, RGA; reporter gene assay

Key words: Monosodium glutamate; reporter gene assay; endocrine disruptor; steroidogenesis; high content analysis; obesity; diabetes; obesogen

\section{Introduction}

Obesity is a global health problem, with an estimated 640 million adults in 2014 and 110 million children and adolescents in 2013 being classed as obese (Lauby-Secretan et al., 2016). Although body fatness and weight gain are largely influenced by modifiable risk factors such as food consumption and exercise, further factors such as exposure to pesticides and/or persistent organic pollutants (POPs) in food or the environment may be involved (Lauby-Secretan et al. 2016). In particular, endocrine disrupting compounds (EDCs), which are exogenous substances or mixtures that alter the function(s) of the endocrine system and consequently cause adverse health effects in an intact organism, or its progeny, or (sub)populations (WHO/IPCS, 2002), have been linked to obesity (Legler et al., 2011).

EDCs whose effects may result in metabolic disorders are termed "obesogens" or metabolic disruptors. Obesogens may act by altering the programming of adipogenesis and increasing energy storage in fat tissue, or by disrupting the neuroendocrine control of appetite and satiety (Janesick and Blumberg, 2016). Environmental exposures during early life can interfere with the epigenetic programming of gene regulation, leading to potential transgenerational effects and 
influencing the risk of obesity in adulthood via adipogenesis, adiposity and body weight gain (Stel and Legler, 2015). In addition, steroid hormones and their receptors have also been linked to the homeostasis of energy metabolism (Mauvais-Jarvis, 2011).

A suspected dietary obesogen which is a widely consumed flavour enhancer is monosodium glutamate (MSG). MSG is composed of sodium mineral ion or salt, attached to glutamic acid, one of the most abundant naturally occurring nonessential amino acids naturally present in our bodies and many foods such as mushrooms, tomatoes and cheese. Once ingested, MSG is broken down into glutamate and sodium ions within the digestive tract and metabolised within the gut. The glutamate that is absorbed, is then transported in the lumen of the intestine through the EAAC-1 (the EAAT-1 or excitatory amino acid transporter) and NaDC-1 (sodium carboxylate transporter) and circulated in the bloodstream throughout the body (Burrin and Stoll, 2009; Janeczko et al., 2007).

MSG is now a relevant aspect of the human diet worldwide. The UK average intake in 1991 was $580 \mathrm{mg} /$ day for the general population but $2.3 \mathrm{~g} /$ day for excessive consumers (Rhodes et al., 1991). More recent studies report an average intake of MSG of $0.4 \mathrm{~g} /$ day in European countries (Beyreuther et al., 2007). In countries such as China, mean MSG consumption has been found to be higher, around $3.1 \mathrm{~g} / \mathrm{day}$ (Shi et al., 2014). In an EFSA report released in 2017, an ADI (acceptable daily intake) of $30 \mathrm{mg} / \mathrm{kg}$ bw per day, was set. Accurately monitoring levels of MSG consumption is difficult because legislation does not enforce any limit on the amount of MSG that restaurants or the food industry can add to their products. Also, food processors and manufacturers are not obligated to list the amount of MSG on their packaging (Food Standards, 2015). 
The mechanism by which MSG may act as an obesogen has not been yet been elucidated (He et al., 2008; He et al., 2011; Khalaf and Arafat, 2015; Miskowiak et al., 1993). In vivo studies link MSG intake to disruption of steroid receptor expression and alteration of levels of hormones such as oestrogen, testosterone or progesterone (Zia et al., 2014; Miskowiak et al., 1993; Rodriguez-Sierra et al., 1982; Nemeroff et al., 1981). These studies demonstrate that MSG may disrupt steroid hormone receptors and/or steroid hormone levels.

We have previously shown that MSG decreases glucagon-like peptide 1 (GLP-1) secretion in a gut in vitro cellular model (Shannon et al., 2017), suggesting a possible mechanism by which MSG may affect glucose regulation and satiety responses. Additionally, as discussed above, studies have demonstrated that MSG may affect sex hormone levels and receptors in vivo. As steroid hormones/receptors play an important role in weight homeostasis, the present study was performed to investigate the potential endocrine disrupting mechanisms of MSG at the level of nuclear receptor transcriptional activity using oestrogen, androgen, progestagen and glucocorticoid Reporter Gene Assays and on steroidogenesis using the H295R steroidogenesis model.

\section{Methods}

\subsection{Chemicals and reagents}

Cell culture reagents were supplied by Life Technologies (Paisley, UK). The standards $17 \beta$-oestradiol, testosterone, progesterone, hydrocortisone, monosodium glutamate

and forskolin were obtained from Sigma-Aldrich (Poole, Dorset, UK). Dimethyl sulfoxide (DMSO) and MTT were also supplied by Sigma-Aldrich. Lysis reagents and 
luciferase assay system was purchased from Promega (Southampton, UK). Hoechst nuclear stain was provided by Thermo Scientific (UK).

\subsection{Cell culture}

Four reporter gene assay (RGA) cell lines, the MMV-Luc (oestrogen responsive), TARM-Luc (androgen and progestagen responsive), TGRM-Luc (glucocorticoid and progestagen responsive) and TM-Luc (progestagen responsive) were previously developed by transforming human mammary gland cell lines with the luciferase gene under the control of a steroid hormone inducible promoter (Willemsen et al., 2004). The H295R human adrenocortical carcinoma cell line, used in the H295R steroidogenesis model, was obtained from the American Type Culture Collection (ATCC CRL-2128, Manassas, VA, USA).

All cell lines were routinely grown in $75 \mathrm{~cm}^{2}$ tissue culture flasks (Nunc, Roskilde, Denmark) at $37{ }^{\circ} \mathrm{C}$ with $5 \% \mathrm{CO}_{2}$ and $95 \%$ humidity. The Reporter Gene Assay (RGA) cell lines were cultured in cell culture medium containing Dulbecco's Modified Eagle Medium (DMEM), 10\% foetal bovine serum and 1\% penicillin streptomycin. For culturing the MMV-Luc cell line, DMEM without phenol red was used due to the weak oestrogenicity of phenol red. The H295R cell line was cultured in cell culture medium containing DMEM with Ham's F-12 nutrient mixture (1:1) supplemented with 1\% ITS + Premix and 2.5\% NuSerum (BD Biosciences, Bedford, MA, US).

\subsection{Cell viability assays}

\subsubsection{MTT assay}

The MTT assay was performed to monitor the cytotoxic effects of test compounds in the RGA cell lines. Briefly, clear flat-bottomed 96-well plates (Nunc, Roskilde, Denmark) were seeded with $4 \times 10^{5}$ cells/ml of the appropriate cell line. After $24 \mathrm{~h}$ 
MSG $(0.5-500 \mu \mathrm{g} / \mathrm{ml})$ was added to the cells at a final $\mathrm{dH}_{2} \mathrm{O}$ (deionised water) concentration of $0.1 \%$. Test compounds were then incubated for $48 \mathrm{~h}$. Viable cells convert the soluble yellow MTT into insoluble purple formazan by the action of mitochondrial succinate dehydrogenase. Following incubation, supernatant was discarded and $50 \mu$ l of MTT solution/well $(5 \mathrm{mg} / \mathrm{ml}$ stock in PBS diluted in 1:2.5 in assay media) was added and cells were incubated for a further $3 \mathrm{~h}$. The supernatant was removed and $200 \mu \mathrm{l}$ of DMSO was added to each well and incubated for 10 min with agitation at $37^{\circ} \mathrm{C}$ to dissolve the formazan crystals. Optical density was measured using a Sunrise spectrophotometer at $570 \mathrm{~nm}$ with a reference filter at $630 \mathrm{~nm}$ (TECAN, Switzerland). Samples were analysed in triplicate wells and in three independent experiments. Viability was calculated as a percentage absorbance of the sample when compared with the absorbance of the solvent control (Fig.1).

\subsubsection{HCA cytotoxicity}

High Content Analysis was used to assess subtle pre-lethal markers of viability in the TARM-Luc cell line. Hoechst 33342 dye at a final concentration of $1.6 \mu \mathrm{M}$ was added to each well and incubated for $10 \mathrm{~min}$ at room temperature and protected from light; after which cells were washed with PBS four times and evaluated on Celllnsight ${ }^{\mathrm{TM}}$ NXT High Content Screening (HCS) Platform (Thermo Fisher Scientific, UK). This instrument analyses epifluorescence of individual cell events using an automated micro-plate reader analyser interfaced with a PC (Dell precision T5600 workstation). Hoechst stain was used to measure cell number and nuclear morphology including nuclear intensity and nuclear area. Data was captured for each plate at $\times 20$ objective magnification in the selected excitation and emission wavelengths of Hoechst dye (Ex/Em 350/461 nm). For each well, 25 field of view images were acquired to examine each parameter (Fig. 2 \& 3). 


\subsection{Reporter gene assays (RGAs)}

RGAs are produced by transfecting cell lines with relevant receptors and incorporating a transactivation step with a signalling protein such as luciferase. The activation of a receptor is then measured through the signalling protein, making it possible to identify both agonism and antagonism of the specific receptor. The range of RGA cell lines used in this study were developed from human mammary gland cell lines by transformation with the luciferase gene under the control of a steroid hormone inducible promoter (Willemsen et al., 2004). In the case of the TARM-Luc cell line, an additional vector was used (pSV-AR0 (coding for human AR)).

The RGA procedure has previously been described by Frizzell et al., (2011). Briefly, cells were seeded at a concentration of $4 \times 10^{5} \mathrm{cells} / \mathrm{ml}, 100 \mu \mathrm{l} / \mathrm{well}$ in white walled, clear and flat bottomed 96-well plates (Greiner Bio-One, Fricken- hausen, Germany). After $24 \mathrm{~h}$, MSG $\left(0.5,5,50,250,500 \mu \mathrm{g} / \mathrm{ml} \mathrm{MSG}\right.$ in $\left.\mathrm{dH}_{2} 0\right)$ and the steroid hormone standards were added to the cells at a final DMSO concentration of $0.1 \%$. The positive controls used with their respective cell lines were: $1.36 \mathrm{ng} / \mathrm{ml}$ 17ß-oestradiol (MMVLuc), $14.5 \mathrm{ng} / \mathrm{ml}$ testosterone (TARM-Luc), $181 \mathrm{ng} / \mathrm{ml}$ hydrocortisone (TGRM-Luc) and $157 \mathrm{ng} / \mathrm{ml}$ progesterone (TM-Luc). A solvent control (0.1\%, v:v DMSO in media) was also included for each cell line. Antagonist tests were carried out by incubating the test compound with the relevant agonist hormone positive control for the cell line being tested. The cells were incubated for $48 \mathrm{~h}$. The supernatant was discarded and the cells washed once with PBS prior to lysis with $30 \mu \mathrm{l}$ cell lysis buffer (Promega, Southampton, UK). Finally, $100 \mu \mathrm{l}$ luciferase substrate (Promega, Southampton, UK) was injected into each well and luciferase activity measured using a Mithras Multimode Reader (Berthold, Other, Germany). RGAs were performed in triplicate for each 
experimental point and in three independent exposures. The response of the cell lines to the compound was measured and compared with the solvent and positive controls.

\subsection{Steroidogenesis assay}

The human adrenal carcinoma cell line H295R has all the important enzymes needed for steroidogenesis and therefore can be used to investigate effects at the level of steroid hormone production. The H295R steroidogenesis assay was performed according to previously described protocols (Gracia et al., 2007; Hecker and Giesy, 2008; Frizzell et al., 2011).

Briefly, the cells were seeded at a concentration of $3 \times 10^{5}$ cells $/ \mathrm{ml}, 1 \mathrm{ml}$ per well, in 24-well plates (BD Biosciences, Bedford, MA, US). The cells were allowed to attach for $24 \mathrm{~h}$ before removing the media and replacing with fresh media containing the test compounds dissolved in DMSO at a final concentration of $0.1 \%(v: v)$. Forskolin was used as a positive control at a concentration of $10 \mu \mathrm{M}$. A solvent control $(0.1 \%$, v:v DMSO in media) was also included. Subsequently, the media was collected from the wells following $48 \mathrm{~h}$ incubation and stored at $-20{ }^{\circ} \mathrm{C}$ until hormone quantification was carried out. The 48-hour incubation time allows the concentrations of these hormones to reach a plateau-phase under these conditions. The AlamarBlue $\AA$ cell viability assay was carried out on the remaining cells in each well. Each experimental point was performed in triplicate with three independent exposures (Fig.1).

\subsection{Hormone detection and quantification}

Frozen media from the H295R steroidogenesis assay was thawed prior to hormone analysis. Oestradiol, testosterone and progesterone levels in the media were quantified by enzyme-linked immunosorbent assays (ELISAs) (Immunodiagnostics, Marburg, Germany). These highly specific kits are based on the principle of 
competitive binding and are intended for the quantitative in vitro diagnostic measurement of oestradiol (0-2000 pg/ml), testosterone $(0-16 \mathrm{ng} / \mathrm{ml})$ and progesterone $(0-40 \mathrm{ng} / \mathrm{ml})$ in serum and plasma, with sensitivities of $9.714 \mathrm{pg} / \mathrm{ml}$, $0.083 \mathrm{ng} / \mathrm{ml}$ and $0.045 \mathrm{ng} / \mathrm{ml}$ respectively. ELISA kits were carried out according to manufacturer's instructions with the exception of the standard curves which were prepared in the same culture medium used for the H295R assay. The intra-assay coefficient of variation was less than $10 \%$. Standard curves were included on each ELISA plate. The mean absorbance obtained from each standard was plotted against its concentration using dose-response curves generated with GraphPad PRISM 5 software.

\subsection{Statistical Analysis}

All values shown are expressed as mean \pm standard deviation (SD) of three independent exposures for the compound tested. Data from the cell viability, reporter gene and steroidogenesis assays were analysed using Microsoft Excel and GraphPad PRISM 5 software (San Diego, CA). A one-way analysis of variance (ANOVA) and Dunnett's Multiple Comparison Test was used to determine significant differences between treatments and the corresponding controls. The mean concentrations were tested for significant difference at the $95 \%$ confidence level, a $P$-value of $\leq 0.05$ was considered as significant $\left(P \leq 0.05^{*}, P \leq 0.01^{* *}\right.$ and $\left.P \leq 0.001^{* * *}\right)$.

\section{Results}

\subsection{Cell viability and cytotoxicity}

MSG was assessed for cytotoxicity by the MTT assay in the MMV-Luc (oestrogen responsive), TM-Luc (progestagen responsive), TGRM-Luc (glucocorticoid and progestagen responsive) and TARM-Luc (androgen and progestagen responsive) cell 
lines. At the various concentrations of MSG tested $(0.5-500 \mu \mathrm{g} / \mathrm{ml})$, no cytotoxicity was observed (Fig.1).

Viability of the H295R cells following $48 \mathrm{~h}$ exposure to MSG $(0.5-500 \mu \mathrm{g} / \mathrm{ml})$ was investigated using the AlamarBlue $\AA$ assay. Cytotoxicity was not observed at any of the concentrations tested (Fig.1). The viability of the cells at the sample concentrations did not differ significantly from the solvent control $(P>0.05)$.

In addition to the MTT assay, subtle pre-lethal markers of viability of the TARM-Luc cell line was investigated due to MSG causing a significant decrease in transcriptional activity in this cell line following exposure to $50-500 \mu \mathrm{g} / \mathrm{ml} \mathrm{MSG}$. However, no significant change in cell number, nuclear area or nuclear intensity was observed by HCA $(P>0.05)($ Fig. $2 \& 3)$.

\subsection{Reporter gene assay}

No agonist response was observed for MSG at any of the test concentrations (0.5-500 $\mu \mathrm{g} / \mathrm{ml})$ in the MMV-Luc, TM-Luc, TGRM-Luc or TARM-Luc. Additionally, no antagonist response was seen for MSG at any of the test concentrations in the MMV-Luc, TMLuc or TGRM-Luc cell lines. However, MSG appeared to exhibit an antagonist response in the androgen and progestagen responsive TARM-Luc cell line, with a dose dependent reduction in androgen response of $33 \%, 36.9 \%$ and $50.6 \%$ (in comparison to the solvent control) at 50,250 and $500 \mu \mathrm{g} / \mathrm{ml} \mathrm{MSG}$, respectively ( $P \leq$ 0.05) (Fig.4). At these concentrations of MSG no reduction in cell viability was observed in the MTT assay (Fig.1). Additionally, as determined by HCA, the cell health markers of cell number, nuclear area and/or nuclear intensity did not significantly differ from the solvent control. Therefore these results appear to be true antagonism of the androgen receptor. 


\subsection{Steroidogenesis}

MSG did not induce any significant changes in the production of oestradiol, testosterone or progesterone as determined by the H295R steroidogenesis assay. The mean concentration of hormones in the treated media did not differ significantly from the solvent control $(P>0.05)$ (Fig.5).

\section{Discussion}

The current cellular in vitro bioassay study on MSG exposure at the level of steroid nuclear receptor signalling and steroidogenesis reports no observed effects on steroid hormone production and no (ant)agonism of the oestrogen, progestogen or glucocorticoid receptors. However, while MSG did not exhibit an agonist response in the androgen receptor, it did induce an antagonist dose dependent response in the androgen receptor. Analysis of all MSG test concentrations confirmed no assay cytotoxicity.

The androgen receptor plays an important role in regulating metabolic homeostasis and is an emerging target for diabetes and obesity. For example, it has been established that testosterone, an androgen receptor agonist, presents anti-obesity actions mediated via the androgen receptor (Mauvais-Jarvis, 2011). Clinical and epidemiological evidence also strongly indicates a major role for sex steroid hormones in the determination of anatomical specificities of fat distribution i.e. the specific region in the body where the fat accumulates, in humans (Dieudonne et al., 1998). Adipocytes (fat cells) express the androgen receptor, suggesting that androgens may contribute to the control of adipose tissue development. Androgen receptor mRNA has been 
demonstrated in human preadipocytes and adipocytes (Dieudonne et al., 1998), with its expression increasing during adipogenesis.

Androgen receptor antagonism has also been linked to a number of detrimental health effects including influencing normal male sexual differentiation and/or fertility (Wong et al., 1995). Men presenting genetic androgen resistance linked to CAG repeats in the androgen receptor gene, which leads to a decrease in androgen receptor-mediated gene transcription, have elevated visceral fat; indicating that a reduction in androgen receptor transcriptional activity, may encourage weight gain in the stomach area (Zitzmann et al., 2003). Men undergoing androgen suppression treatment for prostate cancer present increased body fat mass and serum insulin (Ramasamy et al., 2012). Additionally, clinical trials have shown reduced body fat mass during testosterone replacement therapy (Stanworth and Jones, 2010). Navarro et al., (2016) also highlight that the androgen receptor plays a role in stimulating the incretin effect of the gut hormone GLP-1 and demonstrate that androgen receptor antagonists can decrease glucose-stimulated insulin secretion. Winborn et al., (1987) showed that androgen receptors are present in the stomach and gastrointestinal tract of baboons. Therefore, antagonism of the androgen receptor by MSG may lead to obesogenic effects through disruption of metabolic homeostasis, anti-obesity protection and GLP-1 gut hormone signalling.

Steroidogenesis is a complex process regulated by numerous enzymes and genes which can be disrupted at any step (Hilscherova et al., 2004). Each steroid hormone plays an important role in the maintenance of weight and glucose homeostasis, potentially contributing to the pathogenesis of diabetes and obesity. For example, oestradiol plays a role in regulating energy metabolism and in particular the two oestrogen receptors, ERa and ER $\beta$ (Mauvais-Jarvis, 2011). Modulation of these 
receptor genes within insulin-sensitive tissues shows that oestradiol participates in glucose homeostasis (Mauvais-Jarvis, 2011). Therefore, disruption of oestradiol levels or oestrogen receptors could potentially impact upon glucose homeostasis, resulting in hyper/hypoglycaemia. Low levels of testosterone are an independent risk factor for obesity and epidemiological/clinical studies support the notion that testosterone deficiency in men leads to the development of metabolic syndrome (Stanworth and Jones, 2009). However, the underlying mechanism by which androgens regulate homeostasis is very complex and further exploration is required (Stanworth and Jones, 2009). Progesterone plays a role in both weight and glucose homeostasis with increased levels of progesterone being linked to weight gain (Galletti and Klopper, 1964; Lof et al., 2009). Progesterone also plays a role in insulin secretion, having the ability to inhibit glucose-stimulated insulin secretion from isolated rat islets in a dosedependent manner (Straub et al., 2002). Disruption of progesterone could potentially lead to altered insulin levels, adversely affecting blood glucose regulation increasing diabetes risk (Diabetes UK, 2015).

In the current in vitro bioassay study, no significant difference in oestradiol, testosterone or progesterone hormone production levels were observed when compared to the controls. Similarly, an animal study whereby Wistar rats fed with MSG, also showed no significant alterations in blood testosterone and oestradiol concentrations $(P>0.05)$ (lbegbulem et al., 2016). However, other animal studies such as Nemeroff et al., (1981) and Zia et al., (2014) report alterations in oestradiol, progesterone and testosterone levels. Miskowiak et al., (1993) reported that subcutaneous perinatal administration of MSG to the rat resulted in growth inhibition, obesity, weight decrease in pituitary glands and testes plus lowered testosterone levels. Further studies in rats suggest that MSG may present effects through disruption 
of steroid receptor expression and altering hormones levels such as testosterone, or progesterone. For example, neonatal rats treated orally with MSG presented decreased hypothalamic oestrogen receptor expression (Rodriguez-Sierra et al., 1982). Upon maturation of the treated neonates, the adult rat presented altered serum levels of oestradiol and testosterone. These differing results may be due to differences between in vitro and in vivo studies, neonate or adult models, sex differences, exposure doses and duration. It is also important to note that animal studies employing subcutaneous injection of MSG are rarely applicable in human patho-toxicological investigations (Husarova and Ostatnikova, 2013). Consequently, epidemiological studies and in vitro investigations may provide more relevant and useful findings.

\section{Conclusion}

This in vitro bioassay study shows that MSG can antagonise the androgen receptor in a dose dependent manner and highlights one possible mechanism through which MSG may exert its impact on obesity risk. Additional concerns of these findings include the potential disruption of normal male sexual differentiation and/or fertility; elevated visceral fat; dysregulation of adipose tissue development and the disturbance of antiobesity protection mediated by testosterone via the androgen receptor.

\section{Conflict of Interest}

There is no conflict of interest.

\section{References}


Beyreuther, K., Biesalski, H. K., Fernstrom, J. D., Grimm, P., Hammes, W. P., Heinemann, U., and Walker, R. (2007). Consensus meeting: monosodium glutamate - an update. European Journal of Clinical Nutrition, 61(3), 304-13.

Burrin, D. G., and Stoll, B. (2009). Metabolic fate and function of dietary glutamate in the gut. The American Journal of Clinical Nutrition, 90(8), 850-856.

Connolly, L., Ropstad, E., Verhaegen, S., 2011. In vitro bioassays for the study of endocrine-disrupting food additives and contaminants. Trends in Analytical Chemistry. $30(2), 227 e 236$.

Food Standards Australia New Zealand (2015) MSG in food. Available from: http://www.foodstandards.gov.au/consumer/additives/msg/Pages/default.aspx (Accessed: 30/07/16)

Diabetes, U.K., 2015. What is Diabetes? Available from: https://www.diabetes.org. uk/Guide-to-diabetes/What-is-diabetes/ (accessed: 12.04.15.)

Dieudonne, M. N., Pecquery, R., Boumediene, A., Leneveu, M. C., and Giudicelli, Y. (1998). Androgen receptors in human preadipocytes and adipocytes: regional specificities and regulation by sex steroids. The American Journal of Physiology, 274(6), 1645-1652.

European Food Safety Authority (EFSA) (2017) Re-evaluation of glutamic acid (E 620), sodium glutamate (E 621), potassium glutamate (E 622), calcium glutamate (E 623), ammonium glutamate ( $E$ 624) and magnesium glutamate ( $E$ 625) as food additives. EFSA Journal;15(7):4910.

Frizzell, C., Ndossi, D., Verhaegen, S., Dahl, E., Eriksen, G., Sørlie, M., and Connolly, L. (2011). Endocrine disrupting effects of zearalenone, alpha- and beta-zearalenol at 
the level of nuclear receptor binding and steroidogenesis. Toxicology Letters. 206 (2) 210-217.

Galletti, F., and Klopper, A. (1964). The effect of progesterone on the quantity and distribution of body fat in the female rat. Acta Endocrinologica, 46, 379-386

Gracia, T., Hilscherova, K., Jones, P. D., Newsted, J. L., Higley, E. B., Zhang, X., and Giesy, J. P. (2007). Modulation of steroidogenic gene expression and hormone production of $\mathrm{H} 295 \mathrm{R}$ cells by pharmaceuticals and other environmentally active compounds. Toxicology and Applied Pharmacology, 225(2), 142-53.

Grantham, J. P., and Henneberg, M. (2014). The oestrogen hypothesis of obesity. PloS One, 9(6), e99776.

He K, Zhao L, Daviglus ML, Dyer AR, Van Horn L, Garside D, Zhu L, Guo D, Wu Y, Zhou B and Stamler J (2008) Association of monosodium glutamate intake with overweight in Chinese adults: the INTERMAP study. Obesity 16:1875-1880

He, K., Du, S., Xun, P., Sharma, S., Wang, H., Zhai, F., and Popkin, B. (2011).

Consumption of monosodium glutamate in relation to incidence of overweight in Chinese adults : China Health and Nutrition Survey ( CHNS ) $1-3$. The American Journal for Clinical Nutrition, 93, 1328-1336.

Hecker, M., and Geisy, J., (2008). Novel trends in endocrine disruptor testing: the H295R Steroidogenesis Assay for identification of inducers and inhibitors of hormone production. Analytical and Bioanalytical Chemistry. 390 (1), 287-291.

Hilscherova K, Jones PD, Gracia T, Newsted JL, Zhang X, Sanderson JT, Yu RMK, Wu RSS and Giesy JP (2004) Assessment of the effects of chemicals on the 
expression of ten steroidogenic genes in the H295R cell line using real-time PCR. Toxicological Sciences. 81:78-89

Husarova, V., and Ostatnikova, D. (2013). Monosodium Glutamate Toxic Effects and Their Implications for Human Intake: A Review. JMED Research, 2013, 1-12.

Ibegbulem, C. O., Chikezie, P. C., Ukoha, A. I., and Opara, C. N. (2016). Effects of diet containing monosodium glutamate on organ weights, acute blood steroidal sex hormone levels, lipid profile and erythrocyte antioxidant enzymes activities of rats. Journal of Acute Disease, 1-6.

Janeczko, M. J., Stoll, B., Chang, X., Guan, X., and Burrin, D. G. (2007). Extensive Gut Metabolism Limits the Intestinal Absorption of Excessive Supplemental Dietary Glutamate Loads in Infant Pigs. The Journal of Nutrition, 137(11), 2384-2390.

Janesick, A. S., and Blumberg, B. (2016). Expert Reviews Obesogens : an emerging threat to public health. The American Journal of Obstetrics and Gynecology, 214(5), $559-565$.

Khalaf, H. A., and Arafat, E. A. (2015). Effect of different doses of monosodium glutamate on the thyroid follicular cells of adult male albino rats : a histological study. International Journal of Clincial and Experimental Pathology, 8(12), 15498-15510. Lauby-Secretan, B., Scoccianti, C., Loomis, D., Grosse, Y., Bianchini, F., and Straif, K. (2016). Body Fatness and Cancer — Viewpoint of the IARC Working Group. The New England Journal of Medicine, 375(8), 794-798. 
Legler, J., Hamers, T., Bor, M. V. E. V. D. S. De, Schoeters, G., Ven, L. Van Der, Eggesbo, M., and Trnovec, T. (2011). The OBELIX project: early life exposure to endocrine disruptors. The American Journal of Clinical Nutrition, 94, 1933-1998.

Lof, M., Hilakivi-Clarke, L., Sandin S, S., de Assis, S., Yu, W., and Weiderpass, E. (2009). Dietary fat intake and gestational weight gain in relation to oestradiol and progesterone plasma levels during pregnancy: a longitudinal study in Swedish women. BMC Women's Health, 9, 10.

Mauvais-jarvis, F. (2011). Oestrogen and androgen receptors: regulators of fuel homeostasis and emerging targets for diabetes and obesity. Trends in Endocrinology and Metabolism, 22(1), 24-33

Miskowiak B., Limanowski A., and Partyka M. (1993) Effect of perinatal administration of monosodium glutamate (MSG) on the reproductive system of the male rat. Endokrynologia Polska 44, 497-505.

Navarro, G., Xu, W., Jacobson, D. A., Wicksteed, B., Allard, C., Zhang, G., and Mauvais-Jarvis, F. (2016). Extranuclear actions of the androgen receptor enhance glucose-stimulated insulin secretion in the male. Cell Metabolism, 23(5), 837-851.

Nemeroff, C., Lamartiniere, C., Mason, G., Squibb, R., Hong, J., and Bondy, S. (1981). Marked reduction in gonadal steroid hormone levels in rats treated neonatally with monosodium L-glutamate: further evidence for disruption of hypothalamic-pituitarygonadal axis regulation. Neuroendocrinology, 33(5), 265-7.

Ramasamy, R., Fisher, E., and Schlegel, P. N. (2012). Testosterone replacement and prostate cancer. Indian Journal of Urology, 28(2), 123-128. 
Rhodes, J., Titherley, A. C., Norman, J. A., Wood, R., Lord, D. W., (1991) A survey of the monosodium glutamate content of foods and an estimation of the dietary intake of monosodium glutamate. Food Additives and Contaminants. 8, 663-672.

Rodriguez-Sierra, J., Blaustein, J., Blake, C., Clough, R., and Elias, K.(1982). A decrease of cytosol oestrogen receptors in the hypothalamus as a result of treatment of neonatal rats with glutamate Title. Experimental Brain Research, 48(2), 272-278.

Shannon, M, Green, B, Willars, G, Wilson, J, Matthews, N, Lamb, J, Gillespie, A and Connolly, L (2017) The endocrine disrupting potential of monosodium glutamate (MSG) on secretion of the glucagon-like-peptide-1 (GLP-1) gut hormone and GLP-1 receptor interaction. Toxicology Letters, 265, pp. 97-105.

Shi, Z., Taylor, A. W., Yuan, B., Zuo, H., and Wittert, G. A. (2014). Monosodium glutamate intake is inversely related to the risk of hyperglycemia. Clinical Nutrition, 33(5), 823-828.

Stanworth, R. and Jones, T. (2009). Testosterone in obesity, metabolic syndrome and type 2 diabetes. Frontiers of Hormone Research, 37, 74-90.

Stel, J and Legler, J. (2015) The Role of Epigenetics in the Latent Effects of Early Life Exposure to Obesogenic Endocrine Disrupting Chemicals. Endocrinology, 156, 34663472 ,

Straub, S. G., Sharp, G. W. G., Meglasson, M. D., and Souza, C. J. De. (2002). Progesterone Inhibits Insulin Secretion by a Membrane Delimited, Non-genomic Action. Biosciences Reports, 21(5), 653-666.

WHO/IPCS (World Health Organization/ International Programme on Chemical Safety), 2002. Global Assessment of the State-of-the-Science of Endocrine 
Disruptors.

Available

from:

http://www.who.int/ipcs/publications/new_issues/endocrine_disruptors/en/ (accessed 23.07.15).

Winborn, W.B., Sheridan, P.J., and McGill Jr., H.C. (1987) Sex steroid receptors in the stomach, liver, pancreas and gastrointestinal tract of the baboon. Gastroenterology, 92, 23-32.

Wong, C., Kelce, W., Sar, M., and Wilson, E. (1995). Androgen Receptor Antagonist versus Agonist Activities of the Fungicide Vinclozolin Relative to Hydroxyflutamide. The Journal of Biological Chemistry, 270(34), 19998-20003.

Zia M.S, Qamar K, Hanif R and Khalil M. (2014) Effect of monosodium glutamate on the serum oestrogen and progesterone levels in female rat and prevention of this effect with diltiazem Ayub med coll abbottabad, 26(1): 18-20

Zitzmann, M., Gromoll, J., Eckardstein, A. Von, and Nieschlag, E. (2003). The CAG repeat polymorphism in the androgen receptor gene modulates body fat mass and serum concentrations of leptin and insulin in men. Diabetiologica, 46, 31-39.

Figures 


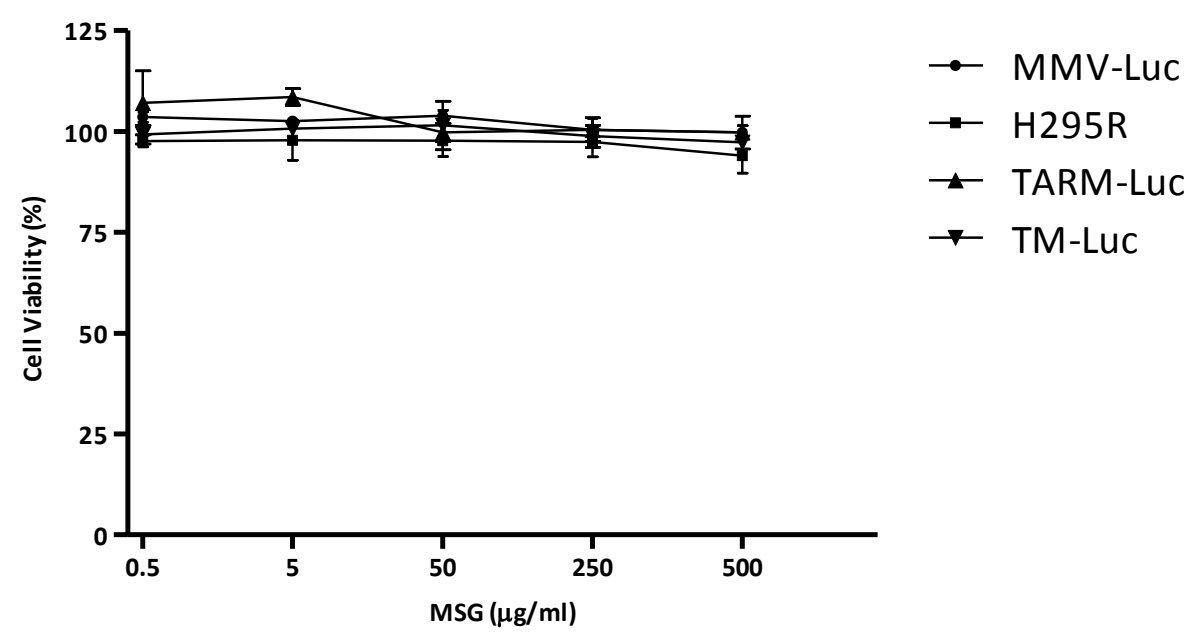

Fig. 1: Viability of the RGA cell lines following exposure to MSG $(0.5-500 \mu \mathrm{g} / \mathrm{ml})$ for 48 h compared to the solvent control, as determined by the MTT assay (for the RGA cell lines) and Alamar Blue assay (for the H295R cell line). The TARM-Luc cell line is specific for the detection of androgens and progestagens, MMV-Luc for oestrogens, TM-Luc for progestagens and H295R cells for oestradiol, testosterone and progesterone. Values are means \pm SEM for three independent exposures in triplicate $(n=3) . P \leq 0.05\left(^{*}\right)$ and $P \leq 0.001\left(^{* * *}\right)$ represent significance.

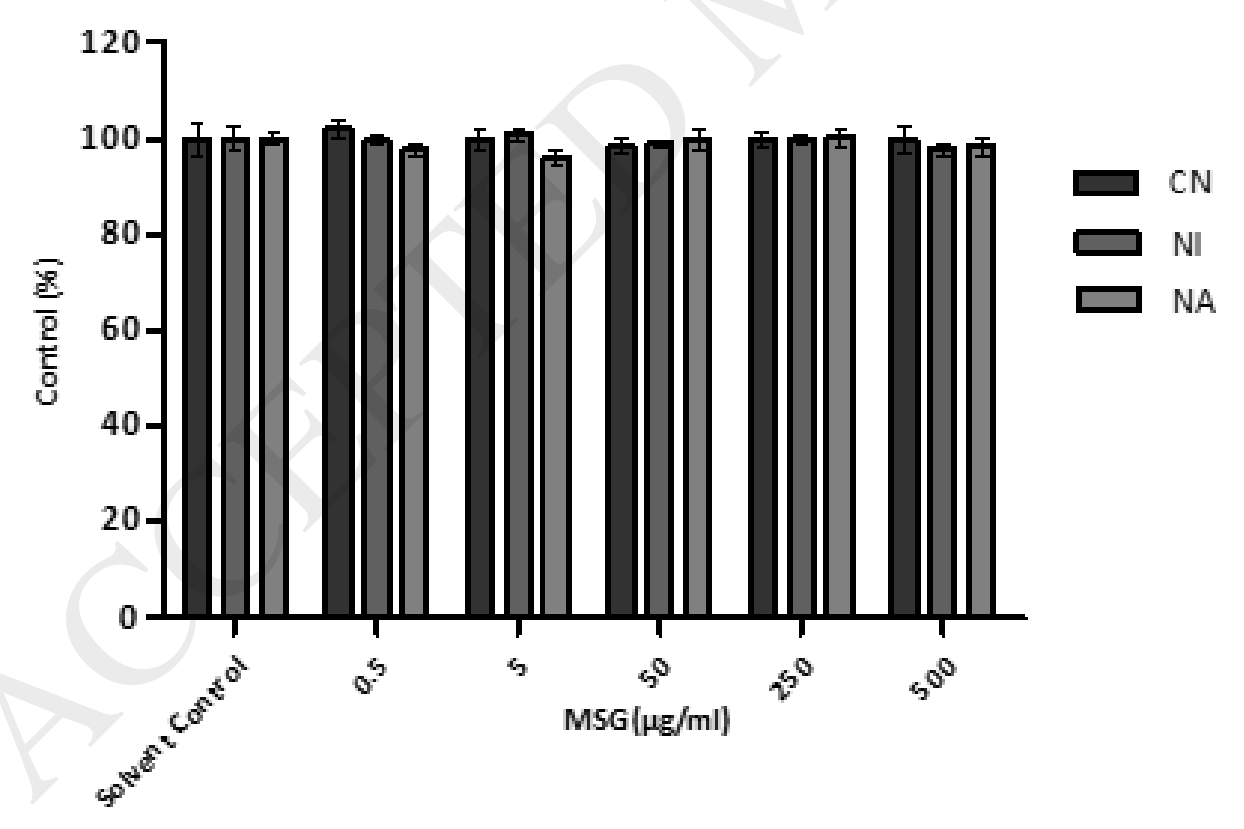

Fig. 2: Cytotoxic effects of MSG at a concentration range of $0.5-500 \mu \mathrm{g} / \mathrm{ml}$ following $48 \mathrm{~h}$ incubation in the TARM-Luc cell line (specific for the detection of androgens and progestagens). A number of endpoints were measured including cell number, nuclear 
area and nuclear intensity. Data is expressed as a percentage of solvent control $\left(\mathrm{dH}_{2} \mathrm{O}\right)$ for each parameter. Values are means \pm SEM for the three independent exposures ( $n$ $=3)$.
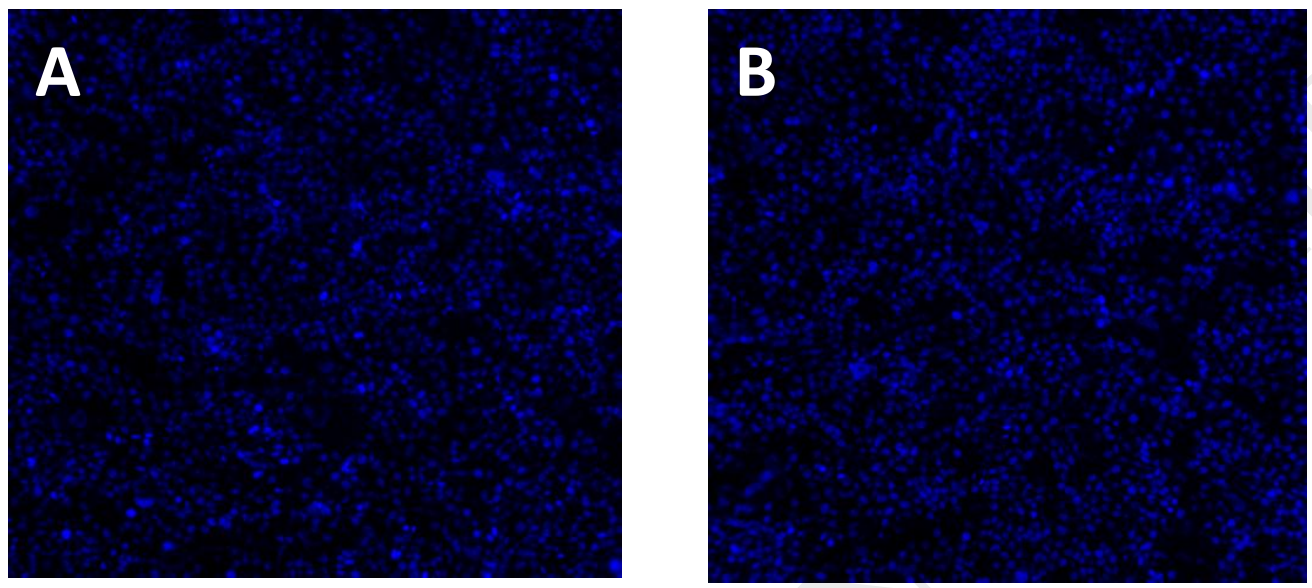

Fig. 3: HCA images for a) solvent control and b) MSG-treated (500 $\mu \mathrm{g} / \mathrm{ml})$ following 48 $h$ exposure to the TARM-LUC cell line (specific for the detection of androgens and progestagens). Each image was acquired at X 20 objective magnification using Hoechst dye (blue; nuclear staining).

A

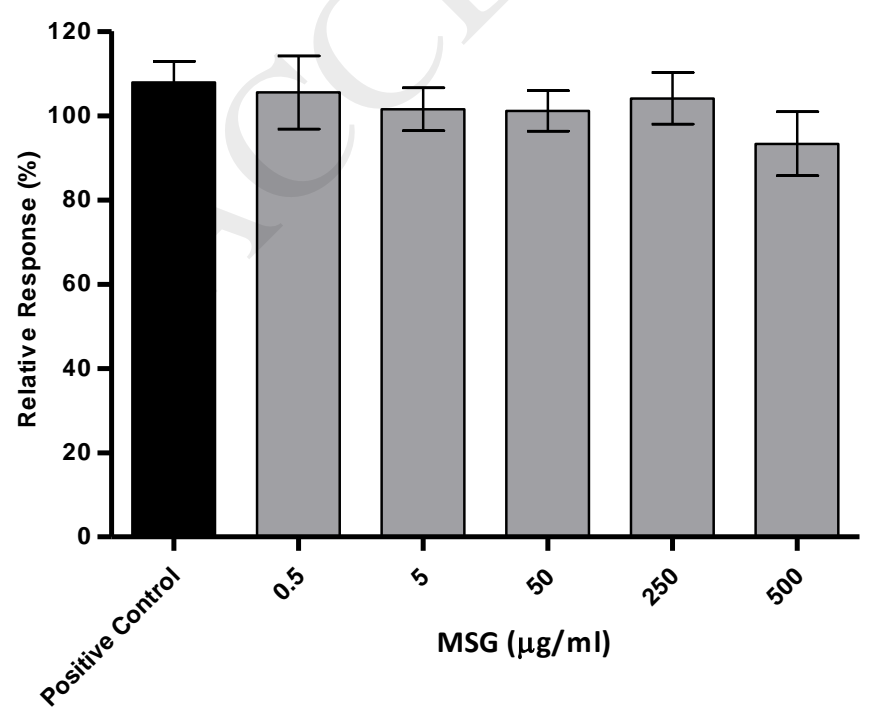

B

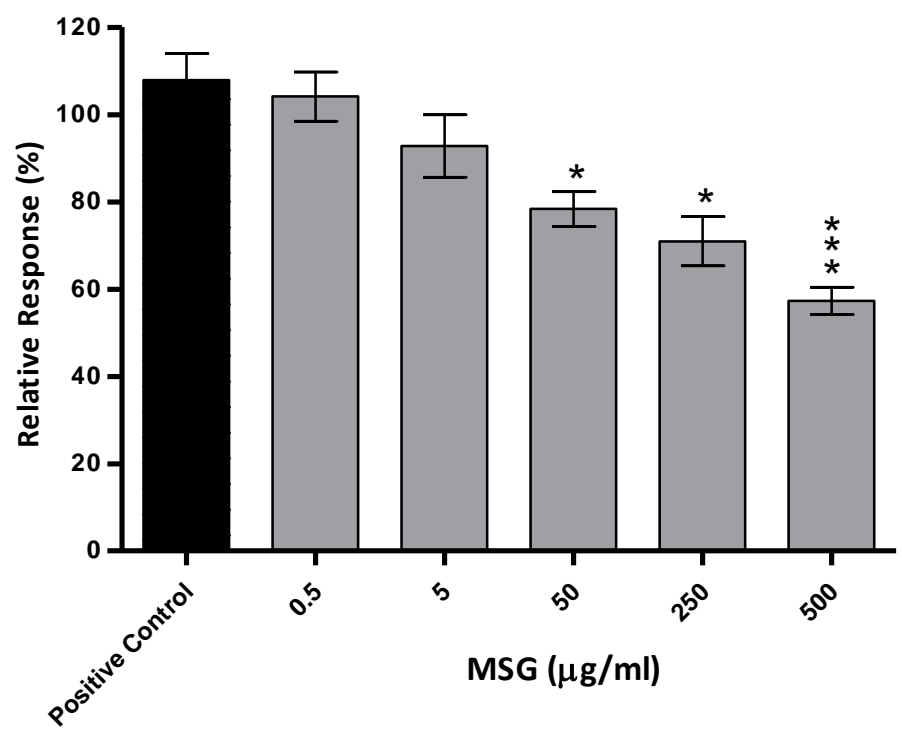




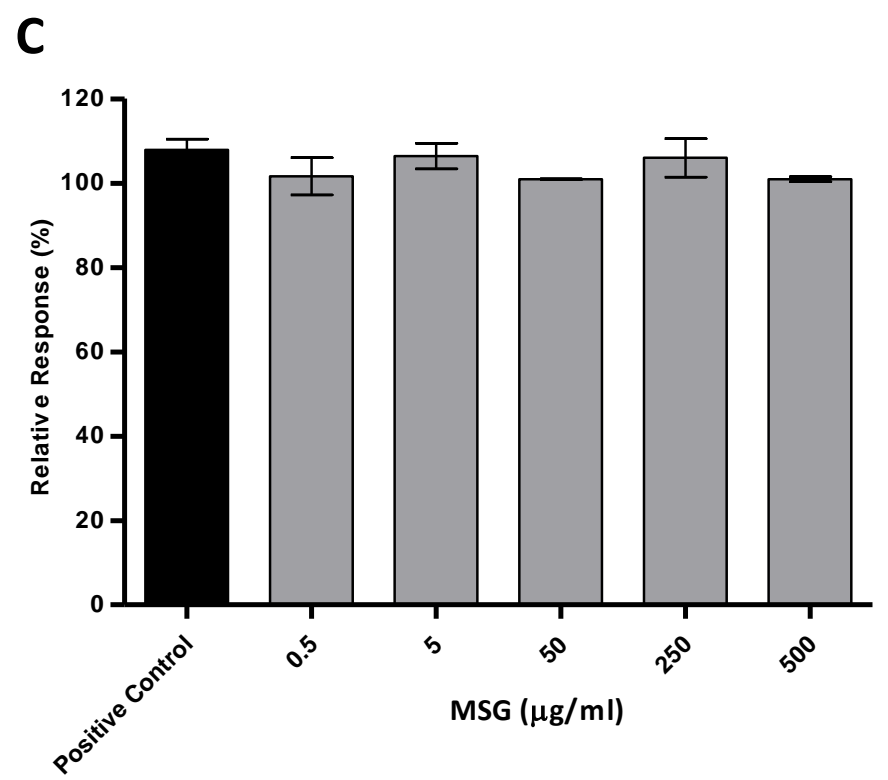

Fig. 5: Antagonist effects in the a) MMV-Luc, b) TARM-Luc cell line, and c) TM-Luc cell line cell lines, following exposure to $0.5-500 \mu \mathrm{g} / \mathrm{ml}$ MSG. Antagonism is measured in the presence of the agonist hormone (relative positive control) $1.36 \mathrm{ng} / \mathrm{ml} 17 \mathrm{~b}$-estradiol, $14.5 \mathrm{ng} / \mathrm{ml}$ testosterone and $157 \mathrm{ng} / \mathrm{ml}$ progesterone). Response is expressed as the percentage response \pm SEM for three independent exposures in triplicate $(n=3) . P \leq 0.05\left({ }^{*}\right)$ and $P \leq$ $\left.0.001^{* * *}\right)$ represent significance. 
A

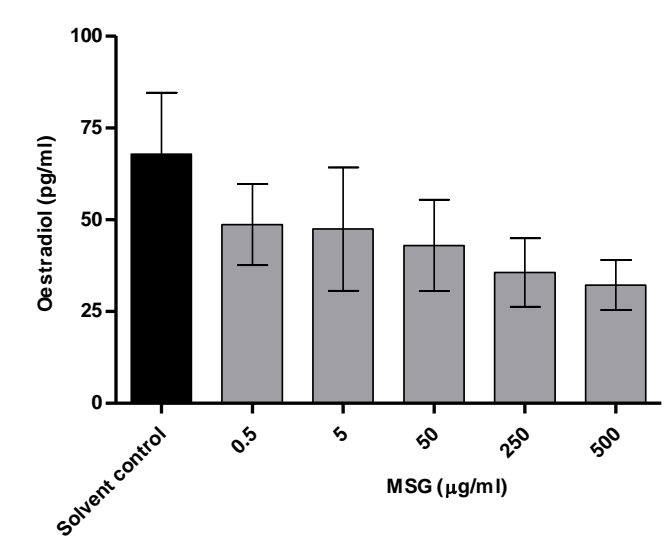

C

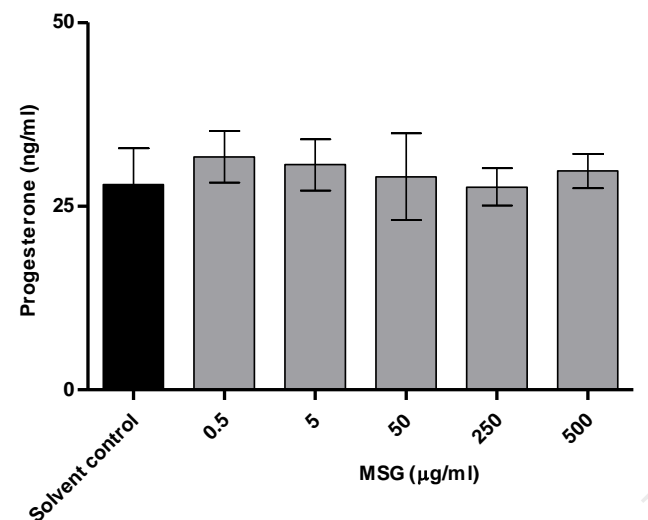

B

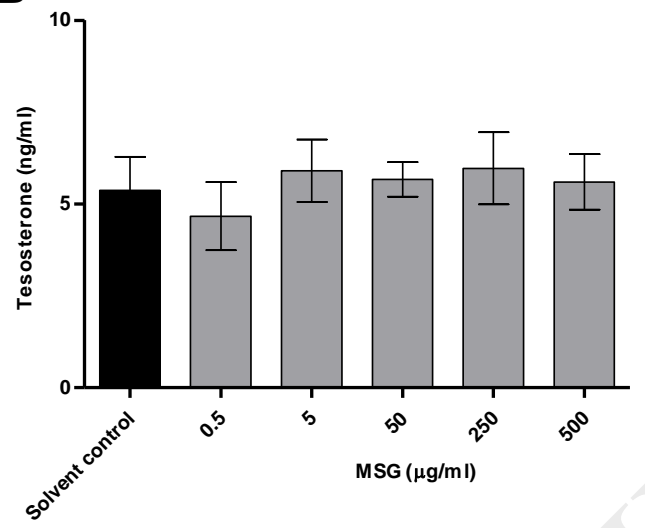

Fig. 5: Production of A) oestradiol, B) testosterone and C) progesterone, by H295R cells following exposure to $0.5-500 \mu \mathrm{g} / \mathrm{ml} M S G$ for $48 \mathrm{~h}$. Values are means \pm SEM for three independent exposures in triplicate $(n=3)$. 